\title{
Managing the COVID-19 pandemic in a fragmented local government setting: A study from Ogan Ilir Regency, Indonesia
}

\author{
Faisal Nomaini ${ }^{1}$, Hoirun Nisyak ${ }^{2}$, Anang Dwi Santoso ${ }^{3}$ \\ ${ }^{1}$ Department of Communication Science, Faculty of Social and Political Sciences, Universitas Sriwijaya, Indonesia \\ 2 Department of International Relations, Faculty of Social and Political Sciences, Universitas Sriwijaya, Indonesia \\ ${ }^{3}$ Department of Public Administration, Faculty of Social and Political Sciences, Universitas Sriwijaya, Indonesia \\ ${ }^{1}$ Corresponding Author: faisalnomaini@fisip.unsri.ac.id
}

Article Info

Article History;

Received:

2021-07-13

Revised:

2021-09-04

Accepted:

2021-11-29

\begin{abstract}
The COVID-19 pandemic marks the importance of coordination, cooperation and collaboration to achieve a reduction in the spread of the virus and reduce its impacts. Although there is a lot of literature that explores how the government works in the COVID-19 pandemic situation, not many studies have examined it at the local government level. Therefore, this study aims to fill this gap by exploring the workings of local governments, and the agencies under them. This research is narrative qualitative research with the main data source from interviews with the Ogan Ilir Regency COVID-19 Task Force for the Acceleration of Response. This study found that despite having a common goal, as a condition of coordination, government agencies have not been able to accomplish this at the action level. The findings of this study reaffirm that the silo mentality still exists in the bureaucracy of local government in Indonesia.
\end{abstract}

Keyword: fragmented local government; COVID-19 pandemic; Indonesia; silo mentality.

DOI: https://doi.org/10.18196/jgpp.v9i1.12301

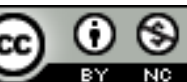

This work is licensed under a Creative Commons Attribution-NonCommercial 4.0 International License.

\section{INTRODUCTION}

The COVID-19 pandemic is a new form of challenge for public organizations that has never happened in previous periods (Chatterji, Roy, \& Chatterjee, 2021; Grint, 2020; Tung, 2021). Leaders of public organizations are still looking for various written instructions from various reports and opinions from academics (Behrens \& Naylor, 2020; Jeong \& Kim, 2021; Wilson, 2020). The government then took over this disastrous situation, crossing the boundaries of traditional power and democratic constitutions. This brings great dependence on society, placing government decisions as one part of individual decision making. Some governments even stipulate disaster and emergency management which is usually used in times of war to protect the population by adopting a strict command and control approach. (Chatterji et al., 2021; Correia, Mendes, Pereira, \& Subtil, 2020; Huang, 2020). Disaster and emergency management at the national level in the current era finds more complicated problems because they are in a fragmented organizational situation and have a strict hierarchy. (Liu, Lin, Shen, \& Lu, 2021). The complexity of each type of situation, technological developments and the dynamics of society also contribute.

Working under a fragmented governance, usually, the organizational structure rests on a network of inter-institutional and cross-sectoral cooperation (Hattke \& Martin, 2020). Therefore, 
this fragmented public organization is expected to be more responsive and effective in dealing with this kind of situation. Unfortunately, another challenge of fragmented governance is aligning many actors with different interests and internal organizational conditions (Sunarharum, Sloan and Susilawati, 2014; Kenawy, Shaw and Osman, 2018). The COVID-19 pandemic comes in the midst of a public administration that has been heavily criticized for being too fragmented, weak coordination, and the emergence of a silo mentality. (Holzhacker, Wittek, \& Woltjer, 2015; Putra \& Matsuyuki, 2019; Talitha, Firman, \& Hudalah, 2019).

From these problems, the question arises whether fragmented and decentralized decisionmaking and action have been able to direct public organizational bodies to achieve common goals. This is complicated by confusion for leaders to set priorities for health or saving the economy because the two are both complex and seem to contradict each other (Choi, 2020; Jeong \& Kim, 2021). Then, the division of tasks in different levels of authority is time consuming, and resource consuming and therefore, it is difficult to achieve a quick and effective collective response. (Mori, Barabaschi, Cantoni, \& Virtuani, 2020; Tung, 2021; Wilson, 2020). On the one hand, in the disaster literature, the centralized situation in decision making is recognized as useful in several studies and produces a common response in crisis situations. (Chatterji et al., 2021; Fraser \& Aldrich, 2021; Wang, Dong, Zhang, \& Luo, 2021). Meanwhile on the other hand, this is a dangerous decision because it relies too much on certain actors.

While many studies on governance of the COVID-19 pandemic in public organizations have focused on national government levels (Bastani, Sheykhotayefeh, Tahernezhad, Hakimzadeh, \& Rikhtegaran, 2020; Djalante et al., 2020; Huang, 2020; Tung, 2021; Wang et al., 2021), there are not many studies exploring at the local government level. In fact, the local government is the government level closest to the community, observing the various dynamics of the COVID-19 pandemic and a number of large demands on health and economic responses and other sectors are accepted at any time. (Gao \& Yu, 2020; Mori et al., 2020; Wang et al., 2021). Local governments are placed as one of the frontlines in managing the COVID-19 pandemic and have various challenges such as limited financial resources due to a number of reallocations and budget refocusing. Another challenge is limited human resources both in terms of quantity and quality. Then there are a number of regulations from the central government that are always changing, making them in a fairly complicated condition because they have to implement various kinds of regulations.

Filling the need for literature, this study focuses on how local governments work, collaborate, communicate with their respective agencies in the midst of the COVID-19 pandemic and the challenges of fragmented organizational governance, trying to remain present and relevant, reducing the spread of the virus while intervene in economics and other fields. This study takes place in the District Government of Ogan Ilir as a representative of the local government which is fragmented because it has 19 offices, 8 agencies, 3 secretariats, 16 subdistricts, 14 sub-districts and 227 villages.

\section{Coordination, Cooperation and Collaboration in Disaster Situations}

In a disaster situation, an effort is needed to collaborate, coordinate and cooperate between government organizations and the community (Hsieh, Wang, Wong, \& Ho, 2021; Liu et al., 2021; Xiao, Peng, \& Xu, 2021). This raises questions as well as debates about how the three are carried out whether using a centralized or decentralized approach. The centralized approach focuses on establishing a coherent emergency strategy while the other, decentralized, focuses on the interactions that emerge between organizations in disaster management. (Downey \& Myers, 2020). Both are important if implemented properly while the opposite happens because there is usually a tension that academics call the crisis management paradox. (Correia et al., 2020).

Meanwhile, coordination, collaboration and cooperation are ambiguous concepts because the three are often used interchangeably and few academics define them differently and differentiate them by looking at the number of interactions. In literature, the three are actually different (Hattke \& Martin, 2020). All three represent related but distinct types of collective action which then impose special incentive structures on different actors and ultimately serve to harmonize different interests. (Hattke \& Martin, 2020). In the context of public-private partnerships in disaster management, predetermined assignments and responsibilities are solutions to various organizational governance problems. (Lee, Watanabe, \& Li, 2019). In 
addition, the problem of overlapping authority in disaster management can be resolved by building stable relationships and mutual trust between the organizations involved.

Among the three previously mentioned forms, coordination is the least intensive form of the three because coordination only involves the alignment of various actors who have a common goal. (Hattke \& Martin, 2020). However, among the actors involved there is no agreement on how to achieve the goal. Coordination in game theory is illustrated as the existence of aligned individual and collective incentives that are carried out continuously. This is facilitated by external actors and a communication process that results in agreement among the actors involved (Im \& Campbell, 2020; Zeemering, 2021).

Then, cooperation requires more intense interaction between the actors involved. Cooperation also requires short-term, informal arrangements. Cooperation occurs in relationships between actors that have strong incentives stemming from collective rational solutions (Hattke \& Martin, 2020).. In this situation collective use is carried out on the basis of such informal arrangements. Collaboration is a form of interaction that requires the most interaction between actors where the actors involved carry out tasks that are interdependent with each other with the aim of achieving goals that they cannot achieve individually. Every actor has an incentive to collaborate, but it can only be used when other actors are also contributing (Sarkar, 2021).

Collaborating among government organizations to fight COVID-19 is not an easy effort, moreover, collaboration involving the community and other actors outside the government (Hattke \& Martin, 2020). This later became a mysterious conundrum for liberal democracies during the COVID-19 pandemic as many authoritarian leaders demonstrated success in reducing the spread of the epidemic by imposing strict isolation measures and mass surveillance. Despite the concerns about the practice, various democratic countries have adopted the practice of authoritarianism to stop COVID-19 (George \& Tarr, 2021; Huang, 2020; Xiao et al., 2021).

\section{Coordination between actors in handling the COVID-19 Pandemic}

Coordination is a concept that is closely related to the completion of a job which is the joint responsibility of various parties. Coordination is an absolute requirement to ensure that all work activities within the organization can run harmoniously and efficiently. Ndraha (2013) explained that conceptually coordination is defined as the authority to move, harmonize, harmonize, and balance specific or different activities so that they are all directed towards certain goals, while functionally, coordination is carried out in order to reduce the negative impact of specialization and make the division of labor more effective. Handoko (2011) explains that coordination is the process of integrating goals and activities in separate units (departments or functional areas) in an organization to achieve goals efficiently and effectively.

Even though every organization absolutely needs coordination, every organization needs the level and type of coordination with different parameters. One of these parameters is determined by the extent to which activities within an organization need to be integrated with the activities of other units. In relation to the need regarding the coordination function within an organization, Handoko (2017)explained that the need for coordination depends on the nature and need for communication in the execution of tasks and the degree of interdependence of the various implementing units. When these tasks require the flow of information between units, a high degree of coordination is best. Hasibuan (2014) describes the dimensions that can be used to determine the effectiveness of the function of a coordination within an organization:

1. Dimensions of Unity of Action. The understanding of the unity of action is that coordination requires the awareness of each member and organizational unit to adapt to each other with other members or organizational units so that they do not run alone.

2. Dimensions of Communication. The emphasis of the communication function on coordination is because a number of units in the organization will be able to be coordinated based on a range which is largely determined by the existence of communication.

3. Dimensions of the Division of Labor. The division of apes is necessary because the goal in an organization is to achieve a common goal which individuals cannot achieve alone. The principle of division of labor is the main foundation in the establishment of coordination in an organization. 
4. Dimensions of discipline. Discipline in coordination is a tool used by superiors to control employees/members of the organization with the aim of changing behavior as well as increasing one's awareness and willingness to obey all organizational rules.

\section{RESEARCH METHOD}

This study aimed to explore how local governments work, mobilizing their agencies to work together to overcome the COVID-19 pandemic from various fields. To achieve this goal, this research uses the qualitative narrative design. In the opinion of Creswell (2014) Qualitative research has the characteristics of a natural setting where qualitative researchers tend to collect field data where participants experience the issue or problem to be studied. Creswell (2014) explained that narrative research is research on the humanities in which the researcher studies a particular situation/condition from an individual or group and asks the individual or group to tell the facts about the particular situation/condition in detail.

Hamidi (2005) explained that the unit of analysis is the unit under study which can be in the form of individuals, groups, objects or a background of social events such as individual or group activities as research subjects. The unit of analysis in this study was the organization/group. The organization/group in question were the Task Force for the Acceleration of COVID-19 Response in Ogan Ilir Regency. The informants in this study consisted of members of the Task Force Team for the Acceleration of COVID-19 Response in Ogan Ilir Regency. Among the informants we interviewed were the Head of the Task Force Team, the Chair of the Working Group of the Task Force Team and the Task Force Team Members.

Before conducting interviews with the three types of informants, we first contacted the National Unity and Community Protection Agency of Ogan Ilir Regency to obtain research permits. After permission was obtained, we then contacted each of the informants to determine the time, date and place of the interview and in advance to confirm their willingness to participate in the interview. Our interviews were conducted face-to-face by applying strict health protocols. Each interview was recorded and we also made field notes to facilitate data analysis. In addition to the interview, we also asked for several documents related to the COVID-19 Response in Ogan Ilir Regency by the Ogan Ilir Regency COVID-19 Response Acceleration Task Force.

Data analysis was guided by Creswell's linear and hierarchical approach (2014). The stages of data analysis are as follows: (1) Processing and preparing data for analysis. These steps include scanning the interview results, sorting and compiling the data depending on the source of the information; (2) Read the entire data. This is done by building a general sense of the data and reflecting on its overall meaning. Researchers write general ideas about the data obtained. (3) Analyze in more detail by coding the data. This step consists of trying to segment the sentence or image into categories and then labeling these categories with terms that actually come from the participants; (4) Perform the coding process to describe the setting, people, locations, and themes to be analyzed; (5) Performing a narrative approach technique in conveying the results of the analysis. This approach can include discussing the chronology of events, certain themes, or the relationship between themes, and (6) Interpreting data or interpreting data. This stage helps researchers in revealing the essence of an idea (Creswell, 2014) .

\section{RESULT AND DICUSSION}

\section{About the COVID-19 Handling Task Force in Ogan Ilir Regency}

One form of policy carried out by the government in priority handling of COVID-19 is the establishment of a Task Force for the Acceleration of Handling COVID-19 through Presidential Decree (Keppres) Number 7 of 2020 dated March 13, 2020. The main objective of this Presidential Decree is as stated in Article 1 is to form a Task Force for the Acceleration of Handling Corona Virus Disease 2019 (COVID-I9). The task force is not only at the national level but also at the provincial and district/city levels. This affirmation is contained in Article 11 Paragraph 1 of the Presidential Decree which reads "Governors and Regents/Mayors shall form a Task Force for the Acceleration of Handling COVID-19 based on the considerations and recommendations of the Chief Executive of the Task Force for the Acceleration of Handling COVID-19". At the national level this task force consists of various elements/agencies chaired by the Head of the National Disaster Management Agency. 
Regional Government Agencies in various regions in Indonesia responded quickly to the Presidential Decree by immediately forming a Task Force for the Acceleration of Handling COVID-19 at the Provincial and Regency/City levels. One of the regencies that also immediately followed up on this Presidential Decree was Ogan Ilir Regency. The Regional Government of Ogan Ilir Regency, South Sumatra Province, through the Regent of Ogan Ilir Regency, on March 19, 2020 issued the Decree of the Ogan Ilir Regent Number 271/KEP/2020 concerning the Task Force for the Acceleration of COVID-19 Response in Ogan Ilir Regency.

The COVID-19 case in Ogan Ilir once reached the yellow zone in May 2020 with a total of 47 COVID-19 cases. Based on the official website of the Ogan Ilir Regency Government, as of Tuesday, March 9, 2021, there were 238 positive cases of COVID-19 with 196 recovered patients and 17 patients who died (quoted from http://corona.oganilirkab.go.id/ accessed on March 13, 2021). The Ogan Ilir Regency task force as a team consisting of various agencies/agencies that is chaired directly by the Head of the Ogan Ilir Regency Regional Disaster Management Agency certainly has various dynamics in its task of suppressing and tackling the spread of COVID-19.

\section{Coordination with the Task Force for the Acceleration of COVID-19 Response in Ogan Ilir Regency}

Adisasmita (2011) defines coordination as an effort to harmonize the work of one department with the tasks of other parts, so as to prevent confusion that can become ineffective. Coordination is needed in every type of organization to integrate every part/department to achieve the goals set by the organization efficiently and effectively. Of course, in practice, there will be differences in the application of coordination based on the types of organizations, especially in two large groups of organizational types, namely public organizations and private organizations. To determine the effectiveness of coordination in the Task Force for the Acceleration of COVID-19 Response in Ogan Ilir Regency, this study uses coordination theory in which there are four dimensions of coordination, namely (1) Unity of Action; (2) Communication; (3) Division of Labor; and (4) Discipline. These four dimensions will be described and analyzed one by one in detail and at the end of the analysis it will be concluded that the effectiveness of each dimension of coordination and the effectiveness of coordination as a whole is a variable.

\section{Unity of Action}

The first dimension of the coordination theory used in this study is the unitary dimension of action. The definition of unity of action is that coordination requires the awareness of each member and organizational unit to adapt to each other with other members or organizational units so that they do not run alone (Hasibuan, 2014). One form of operationalization of the unity of action within the organization is the existence of a chain of command. In government organizations, Robbins and Judge (2008) states the form of an unbroken line of authority starting from the top level of an organization which is continued to the lowest level and also to explain who reports to whom.

The research findings show that the chain of command is enforced in accordance with directives that are in accordance with the various laws and regulations above where, each Working Group (Pokja) on the Task Force Team is well controlled with clear work for each working group. Then, the control mechanism on the compliance aspect is data-based. Control is also carried out by reporting the implementation of tasks in stages. The BPBD of Ogan Ilir Regency is the organization appointed as the coordinator for the acceleration of the COVID-19 response as it is the government agency for disaster management.

We also found that the regulation at the national level regarding the Task Force Team is the Minister of Home Affairs Circular No. 440/2622/SJ regarding the Establishment of the Regional COVID-19 Handling Acceleration Task Force. Furthermore, the Provincial Government issued a Decree of the Governor of South Sumatra Number 180/KPTS/Dinkes/2020 concerning the Establishment of a Task Force for the Acceleration of Handling COVID-19 in South Sumatra Province which was followed up by the Regent of Ogan Ilir through the Decree of the Regent of Ogan Ilir Number 271/KEP/2020 concerning the Task Force Team. Acceleration of COVID-19 Response in Ogan Ilir Regency. The handling of COVID-19 carried out by the Task Force Team was further updated with the issuance of the Decree of the Ogan Ilir Regent Number 453/KEP/BPBD/2020 concerning the Ogan Ilir Regency COVID-19 Handling Task Force. With 
this change in the legal basis, it will also have an impact on changes in the main tasks and divisions of work in the Task Force Team. This factor can actually be categorized as an external factor because the Task Force Team and even the Regional Government itself only act as recipients of decisions if the decision has been declared officially enforced by the Central Government.

\section{Communication}

The second dimension used in this study to determine the effectiveness of the coordination function is the communication dimension. Theoretically, the communication dimension affects the coordination of a number of units within an organization. Communication targets that a thought, meaning and message are shared equally. Byker and Anderson in Cangara (2010) states that communication in humans is the sharing of information between two or more people. Furthermore, according to Pearson and Nelson in Cangara (2010) that communication is a process of understanding and sharing meaning. Information or messages conveyed in communication can be in the form of verbal or non-verbal communication. Verbal communication is oral and written communication using words. Furthermore, non-verbal communication is communication that is conveyed without using words (Kusumawati, 2016).

In relation to communication, we found that the validity and clarity of the sources of information circulating both for the internal Task Force Team and for publication have reliable data sources. Before the sources of information are circulated, a procedure for verifying the validity of the information sources is carried out first. This is because the implementation of information dissemination and communication processes is in accordance with the Task Force Team's command line. Dissemination of information is carried out by the Working Group, which has the main function of communication and information.

In this case, the process of providing information directly to the public regarding the prevention, mitigation, and dangers of COVID-19 takes a long time due to the large number of sub-district villages with far apart locations. Based on the research results, providing information directly to the public regarding the COVID-19 pandemic has a higher level of effectiveness when compared to providing information only through the media. The Task Force Team in responding to these obstacles generally is to provide information and education to the community by delegation, for example to parties who are elements of health at the village level or by involving elements of village government. This second factor is actually external because the issue of the number of villages and the distance between village locations that are far apart are not elements that are internal to the Ogan Ilir Regency COVID-19 Task Force for Acceleration Response.

\section{Division of work}

The third dimension of coordination in this study is the dimension of division of labor. The division of labor is necessary because the goal in an organization is to achieve common goals which individuals cannot achieve alone. The principle of division of labor is the main foundation in the establishment of coordination in an organization (Hasibuan, 2014). The principle of division of labor basically must be applied in any line of organization. The increasingly protracted COVID-19 pandemic has made the government take a policy to establish a Regional COVID-19 Handling Acceleration Task Force based on the Minister of Home Affairs Circular No. 440/5876/SJ Year 2020.

We found that the authority, function, and role within the structure of the Task Force Team were assigned and carried out in accordance with the provisions of the laws and regulations. The division of labor carried out is based on the main tasks and functions and is structured and systematic. The BPBD of Ogan Ilir Regency is able to carry out its role as a director and coordinator on the work carried out by the Task Force Team. There is good synergy and adaptability in each working group. Adjustments to the division of labor in the field under certain conditions can be carried out properly.

The structure of the Task Force Team which consists of various elements (Agencies/OPD) makes it difficult to obtain work synchronization. However, it is important to note that this factor occurred in the early days of the formation of the Task Force for the Acceleration of COVID-19 Response in Ogan Ilir Regency. Each agency has different work guidelines so that in the early days the Task Force Team was formed it was still necessary to have uniform vision, mission, 
goals and work patterns in each working group consisting of various agencies. The coordination process is still looking for effective and efficient forms and patterns in the early days of the Task Force Team being formed. This factor is a factor whose scope of existence is internal to the Task Force Team itself. However, the existence of this third inhibiting factor did not last long as the unity of action, communication, division of labor, obedience to the main tasks and functions, and so on became effective along with a stronger sense of togetherness within the team.

\section{Discipline}

Sastrohadiwiryo in (2016)) explains that work discipline is an attitude of respect, respect, obedience and obedience to the applicable regulations, both written and unwritten regulations and being able to carry them out and not refusing to accept sanctions if they violate the duties and authorities that have been given. According to Sutrisno in Susi (2016) Discipline is an attitude of respect that grows in employees towards the rules and regulations of the company so that they can adapt to the rules and regulations of the company. According to Darmawan in Susi (2016) Discipline is an attitude, behavior and action that is in accordance with the regulations of the organization, either in written form or not.

With regard to discipline, the control mechanism for each Pokja is carried out by the coordinator of the respective agency and reported to the Daily Chair of the Task Force Team. Accountability of work and budget is submitted to Regional Government Leaders based on attached documents/evidence. The application of rewards and punishments is applied with reference to the legislation. The form of compliance and accountability for work carried out by the team can be seen through absenteeism and documentation that can be accounted for by the Task Force Team to the Regional Government. There is a non-financial rewarding application to improve work discipline and incentives for individuals who are members of the Task Force Team. In the punishment mechanism, BPBD as the coordinator of the Task Force Team also applies a form of punishment in accordance with the applicable rules. As a conclusion at the end of the overall analysis of the dimensions of this coordination effectiveness variable, it will be described in the form of a table which is a point-by-point conclusion from all the analysis carried out, namely as follows:

\section{Discussion}

This study aims to explore how the Ogan Ilir Regency Government works, mobilizing its agencies to work together to overcome the COVID-19 pandemic from various fields. We highlight four main aspects in the concept of coordination, namely unity of action, communication, division of labor, and discipline. Our findings show that in general, there are no problems in coordination between government agencies in handling the COVID-19 pandemic in Ogan Ilir Regency. This is because the goals of each actor are aligned with the collective goals of team building (Correia et al., 2020; Liu et al., 2021). Even so, how the actors harmonize their actions is still a problem even though at the level of goals there is no problem.

More precisely, our analysis discovers that in the first dimension, namely unity of action, the chain of command is enforced in accordance with legislative and regulatory directives and the coordination principle. Each Working Group (Pokja) in the Task Force Team is well-managed, with clearly defined job responsibilities for each group. The compliance control mechanism is data-driven. Control is also accomplished by stage-by-stage reporting on the completion of tasks. The BPBD of Ogan Ilir Regency is capable of carrying out its coordination responsibilities. Then, in the communication component, the validity and clarity of information sources circulated both internally and for publishing can be accounted for. Prior to disseminating sources of information, a procedure for validating the sources of information is carried out. Implementation of a process for information distribution and communication in accordance with the Task Force Team's command line. The Working Group is responsible for information dissemination. Its primary function is communication and information.

The third dimension is labor division. The Task Force Team's power, function, and role within its structure are delegated and carried out in line with the provisions of the legislation. The division of labor is structured and methodical and is based on the primary duties and functions. The BPBD of Ogan Ilir Regency is capable of acting as a director and coordinator for the Task Force Team's activity. Each working group has a high degree of cohesion and 
adaptability. Adjustments to the division of work in the field are possible under certain circumstances. Finally, there is discipline. The control mechanism for each Pokja is administered by the coordinator of the relevant agency and is reported to the Task Force Team's Daily Chair. Work and budget accountability is communicated to Regional Government Leaders via associated documents/evidence. Reward and punishment are administered in accordance with applicable rules and regulations.

Although previous studies recommend establishing formal relationships so that actors can help each other solve problems with each other (Hattke \& Martin, 2020), we found that the development of formal relations carried out through the Decree of the Ogan Ilir Regent Number 271/KEP/2020 concerning the Task Force for the Acceleration of COVID-19 Response in Ogan Ilir Regency, was not simply able to overcome various obstacles that had been embedded in public organizations. Differences in human resources, budgetary resources and also mastery of technology as confirmed in previous studies were also found in this study hampering the alignment of the performance of local governments. (Huang, 2020).

Taken to a higher level, namely cooperation, various problems arise when each actor begins to pursue individual targets which are the main performance indicators for each organization. (Hsieh et al., 2021; Xiao et al., 2021). Although the actors realize that long-term relationships will have considerable benefits, the relationships found in this study tend to be short-term relationships with relatively lower risks. We also find that cooperation in the previous period is a social learning that can reduce tensions between actors who work together. (Downey \& Myers, 2020; Teter, 2020). Communication will of course tend to be fluid.

As collaboration requires all actors to be involved in achieving organizational goals, namely reducing victims of COVID-19 and its various impacts, it is hoped that each actor will be able to share risks and build long-term relationships based on professional values and social norms. (Ceresia \& Misuraca, 2020; Correia et al., 2020; Ding \& Riccucci, 2020; Huang, 2020). The research findings show that it is difficult to implement given the silo mentality and the already fragmented condition of local governments, making collaboration difficult.

Silos can inhibit employee productivity since they are constructed in the Weberian sense of a network of reporting linkages that can be broken only through restructuring (Krishnamurthy, 2015). On the other hand, silos can also refer to the procedures that govern the flow of information inside and across components of an organization or system (Lee and Jun, 2021). They agreed on small feedback loops for organizational self-correction and on siloed decisionmaking as a communication obstacle (on and 2017, no date; Chisita, Congress and 2012, 2006). When processes are siloed, they inhibit information sharing between units or departments. These activities entail the interchange of information, objectives, tools, and other vital operations and resources necessary for the existence of the organization. Thus, silos operate as process barriers, obstructing collaboration and interlocking actions inside an organization.

Local governments that are too fragmented may on the one hand make the government more focused on work, and on the other hand make work more centralized and prevent frontline bureaucrats from working. (Hsieh et al., 2021). This is not only happening in the COVID-19 pandemic situation because local governments have long received such criticism, it is the result of decentralization of power and new public management. (Criado \& Guevara-Gómez, 2021; Downey \& Myers, 2020). The COVID-19 pandemic demands the involvement of various actors and different perspectives, diverse ideas and of course sometimes compete with each other to be the winner. The COVID-19 pandemic is also a moment to underscore the importance of mechanisms to harmonize various government authorities and agencies and combine local awareness and responsibility with various kinds of support at the national level. (Parrado \& Galli, 2021; Wong, 2021; Xiao et al., 2021).

\section{CONCLUSION}

This study aims to explore how local governments work, in the midst of fragmented conditions, struggling to fight the COVID-19 pandemic. The research findings show that although there are no serious problems from the coordination aspect because basically the goals of each actor and the collective goals have been aligned, various problems arise in the stages of cooperation and collaboration. This is because each actor, despite having a common goal, has not been able to accomplish it at the action level. This research also confirms the old 
disease of public organizations, namely the silo mentality, as a result of fragmentation and overly specific decentralization.

This study confirms that the COVID-19 pandemic provides a huge space to evaluate coordination, cooperation, and collaboration between the public sector. The silo mentality that has become a long-standing disease of public organizations, even in a complicated situation like this, still occurs. Some research limitations that can be used as recommendations for further research are for example case studies at different levels of government such as city/district, province and central, for example, if viewed from a multi-level governance perspective.

\section{ACKNOWLEDGEMENT}

The research/publication of this article was funded by DIPA of Public Service Agency of Universitas Sriwijaya 2021. SP DIPA-023.17.2.677515 /2021, On November 23, 2020. In accordance with the Rector's Decree Number: 0010/ UN9/ SK.LP2M.PT/2021, On April 28, 2021".

\section{REFERENCE}

Adisasmita, R. (2011) Manajemen Pemerintah Daerah. Yogyakarta: Penerbit Graha Ilmu.

Bastani, P. et al. (2020) 'Reflections on COVID-19 and the ethical issues for healthcare providers', International Journal of Health Governance. Emerald Group Publishing Ltd., 25(3), pp. 185-190. doi: 10.1108/IJHG-05-2020-0050.

Behrens, L. L. and Naylor, M. D. (2020) “We are Alone in This Battle": A Framework for a Coordinated Response to COVID-19 in Nursing Homes', Journal of Aging and Social Policy. Routledge, 32(4-5), pp. 316-322. doi: 10.1080/08959420.2020.1773190.

Cangara, H. (2010) Pengantar Ilmu Komunikasi. Jakarta: Rajawali Press.

Ceresia, F. and Misuraca, R. (2020) 'Critical issues in the management of the first phase of the COVID-19 pandemic in Italy: The role of some organizational flaws on the adoption of collaborative governance models', Revista de Ciencias Sociales. Universidad del Zulia, 26(3), pp. 11-19. Available at: https://www.scopus.com/inward/record.uri?eid=2-s2.085091165316\&partnerID=40\&md5=f212058e2566c6673e8eebf6fb11bbf6.

Chatterji, T., Roy, S. and Chatterjee, A. (2021) 'Global contagion and local response: the influence of centre-state relations and political culture in pandemic governance', Asian Pacific Journal of Public Administration. Routledge. doi: 10.1080/23276665.2020.1870866.

Chisita, C., Congress, I. A.-W. L. and I. and 2012, undefined (2006) 'Rising above the grain silo mentality through collaboration: Creating opportunities between the LIS educators and Practionners in developing countries', cf4-www.ifla.org, 4(2). Available at: https://cf4www.ifla.org/past-wlic/2012/213-chisita-en.pdf (Accessed: 18 October 2021).

Choi, Y. J. (2020) 'The Power of Collaborative Governance: The Case of South Korea Responding to COVID-19 Pandemic', World Medical and Health Policy. Blackwell Publishing Ltd, 12(4), pp. 430-442. doi: 10.1002/wmh3.376.

Correia, P. M. A. R. et al. (2020) 'The combat against covid-19 in portugal, part ii: How governance reinforces some organizational values and contributes to the sustainability of crisis management', Sustainability (Switzerland). MDPI AG, 12(20), pp. 1-13. doi: $10.3390 /$ su12208715.

Creswell, J. W. (2014) Research Design: Qualitative, Quantitative, and Mixed Methods Approaches. 4th edn. Thousand Oaks: SAGE Publications. doi: 10.1007/s13398-014-0173-7.2.

Criado, J. I. and Guevara-Gómez, A. (2021) 'Public sector, open innovation, and collaborative governance in lockdown times. A research of Spanish cases during the COVID-19 crisis', Transforming Government: People, Process and Policy. Emerald Group Holdings Ltd. doi: 10.1108/TG-08-2020-0242.

Ding, F. and Riccucci, N. M. (2020) 'The value of alumni networks in responding to the public 
administration theory and practice: Evidence from the COVID-19 pandemic in China', Administrative Theory and Praxis. Routledge, 42(4), pp. 588-603. doi: 10.1080/10841806.2020.1798694.

Djalante, R. et al. (2020) 'Review and analysis of current responses to COVID-19 in Indonesia: Period of January to March 2020', Progress in Disaster Science. Elsevier BV, 6, p. 100091. doi: 10.1016/j.pdisas.2020.100091.

Downey, D. C. and Myers, W. M. (2020) 'Federalism, Intergovernmental Relationships, and Emergency Response: A Comparison of Australia and the United States', American Review of Public Administration. SAGE Publications Inc., 50(6-7), pp. 526-535. doi: 10.1177/0275074020941696.

Fraser, T. and Aldrich, D. P. (2021) 'The dual effect of social ties on COVID-19 spread in Japan', Scientific Reports, 11(1). doi: 10.1038/s41598-021-81001-4.

Gao, X. and Yu, J. (2020) 'Public governance mechanism in the prevention and control of the COVID-19: information, decision-making and execution', Journal of Chinese Governance. Taylor and Francis Ltd., pp. 1-20. doi: 10.1080/23812346.2020.1744922.

George, A. J. and Tarr, J.-A. (2021) 'Addressing Australia's collaboration "problem": Is there a Brave New World of innovation policy post COVID-19?', Australian Journal of Public Administration. Blackwell Publishing Ltd. doi: 10.1111/1467-8500.12470.

Grint, K. (2020) 'Leadership, management and command in the time of the Coronavirus', Leadership, 16(3), pp. 314-319. doi: 10.1177/1742715020922445.

Hamidi (2005) Metode Penelitian Kualitatif: Aplikasi Praktis Pembuatan Proposal Dan Laporan Penelitian. Malang: UMM PRESS.

Handoko, T. H. (2011) Manajemen Personalia dan Sumber Daya Manusia. Yogyakarta: BPFE.

Handoko, T. H. (2017) Manajemen Sumber Daya Manusia (Edisi Revisi. Jakarta: PT Bumi Aksara.

Hasibuan, M. S. P. (2014) Manajemen Sumber Daya Manusia. Jakarta: Bumi Aksara.

Hattke, F. and Martin, H. (2020) 'Collective action during the Covid-19 pandemic: The case of Germany's fragmented authority', Administrative Theory and Praxis. Routledge, 42(4), pp. 614-632. doi: 10.1080/10841806.2020.1805273.

Holzhacker, R. L., Wittek, R. and Woltjer, J. (2015) Decentralization and governance in Indonesia, Decentralization and Governance in Indonesia. Springer International Publishing. doi: 10.1007/978-3-319-22434-3.

Hsieh, C.-W. et al. (2021) 'A whole-of-nation approach to COVID-19: Taiwan's National Epidemic Prevention Team', International Political Science Review. SAGE Publications Ltd. doi: $10.1177 / 01925121211012291$.

Huang, I. Y.-F. (2020) 'Fighting COVID-19 through Government Initiatives and Collaborative Governance: The Taiwan Experience', Public Administration Review. Blackwell Publishing Ltd, 80(4), pp. 665-670. doi: 10.1111/puar.13239.

Im, T. and Campbell, J. W. (2020) 'Coordination, incentives, and persuasion: South korea's comprehensive approach to covid-19 containment*', Korean Journal of Policy Studies. Seoul National University - Graduate School of Public Administration, 35(3), pp. 119-139. Available at: https://www.scopus.com/inward/record.uri?eid=2-s2.085102016220\&partnerID=40\&md5=a03d047b1d960290bc6a8df58ea363b3.

Jeong, B. G. and Kim, S.-J. (2021) 'The Government and Civil Society Collaboration against COVID-19 in South Korea: A Single or Multiple Actor Play?', Nonprofit Policy Forum. De Gruyter Open Ltd, 12(1), pp. 165-187. doi: 10.1515/npf-2020-0051.

Kenawy, E., Shaw, D. and Osman, T. (2018) Exploring the challenges for effective spatial planning in new urban development: The case of ecotourism in Egypt, New Cities and Community Extensions in Egypt and the Middle East: Visions and Challenges. doi: 10.1007/978-3-319- 


\section{5-4_7.}

Krishnamurthy, R. (2015) 'Use of social media technologies for intra-Agency collaboration: Evidence from us local governments', in ACM International Conference Proceeding Series, pp. 325-326. doi: 10.1145/2757401.2757456.

Kusumawati, T. I. (2016) 'Komunikasi Verbal dan Nonverbal', Jurnal Al-Irsyad Pendidikan dan Konseling. Medan: Fakultas Ilmu Tarbiyah dan Keguruan UIN Sumatera Utara, 6(2).

Lee, J. S. and Jun, S. P. (2021) 'Privacy-preserving data mining for open government data from heterogeneous sources', Government Information Quarterly. Elsevier Ltd, 38(1). doi: 10.1016/j.giq.2020.101544.

Lee, Y., Watanabe, K. and Li, W.-S. (2019) 'Public private partnership operational model - A conceptual study on implementing scientific-evidence-based integrated risk management at regional level', Journal of Disaster Research. Fuji Technology Press, 14(4), pp. 667-677. doi: 10.20965/jdr.2019.p0667.

Liu, Z. et al. (2021) 'Collaborative neighborhood governance and its effectiveness in community mitigation to COVID-19 pandemic: From the perspective of community workers in six Chinese cities', Cities. Elsevier Ltd, 116. doi: 10.1016/j.cities.2021.103274.

Mori, E. et al. (2020) 'Local governments' communication through Facebook. Evidences from COVID-19 pandemic in Italy', Journal of Public Affairs. doi: 10.1002/pa.2551.

Ndraha, T. (2013) Budaya Organisasi. Jakarta: PT Rineka Cipta.

on, T. M.-P. of the I. C. and 2017, undefined (no date) 'Effects of silo mentality on corporate ITC's business model', academia.edu. Available at: https://www.academia.edu/download/67198920/picbe-2017-0105.pdf (Accessed: 18 October 2021).

Parrado, S. and Galli, D. (2021) 'Intergovernmental veto points in crisis management: Italy and Spain facing the COVID-19 pandemic', International Review of Administrative Sciences. SAGE Publications Ltd. doi: 10.1177/0020852320985925.

Puryana, D. E. (2016) 'Hubungan Koordinasi Dengan Disiplin Kerdinasi Dengan Disiplin Kerja Pegawai Pada Kantor Inspektorat Daerah Kota Samarinda. E-Journal', Ilmu Pemerintahan. Samarinda: FISIP Universitas Mulawarman, 4(2), p. : 843-856.

Putra, D. I. and Matsuyuki, M. (2019) 'Disaster management following decentralization in Indonesia: Regulation, institutional establishment, planning, and budgeting', Journal of Disaster Research. Fuji Technology Press, 14(1), pp. 173-187. doi: 10.20965/JDR.2019.P0173.

Robbins, S. P. and Judge, T. A. (2008) Essential Organisational Behaviour. Upper Saddle River. New Jersey: Pearson Education Inc.

Sarkar, S. (2021) 'Breaking the chain: Governmental frugal innovation in Kerala to combat the COVID-19 pandemic', Government Information Quarterly. Elsevier Ltd, 38(1). doi: 10.1016/j.giq.2020.101549.

Sunarharum, T. M., Sloan, M. and Susilawati, C. (2014) 'Re-framing planning decision-making: Increasing flood resilience in Jakarta', International Journal of Disaster Resilience in the Built Environment. Emerald Group Publishing Ltd., 5(3), pp. 230-242. doi: 10.1108/IJDRBE-02-2014-0015.

Susi, Y. (2016) 'Indikator-indikator Kedisipinan Kerja Karyawan Pada Hotel Kini di Pontianak', Ilmiah Mahasiswa Manajemen., 1(6), pp. 1362-1372.

Talitha, T., Firman, T. and Hudalah, D. (2019) 'Welcoming two decades of decentralization in Indonesia: a regional development perspective', Territory, Politics, Governance. Routledge. doi: $10.1080 / 21622671.2019 .1601595$.

Teter, W. (2020) 'Fostering problem driven collaboration in a development context: The ASEAN 
study of health workforce governance', Asia Pacific Journal of Public Administration. Routledge, 42(2), pp. 89-110. doi: 10.1080/23276665.2020.1753222.

Tung, L. T. (2021) 'Success in combating a pandemic: Role of fast policy responses', World Development Perspectives. Elsevier Ltd, 21. doi: 10.1016/j.wdp.2020.100285.

Wang, C. et al. (2021) 'Community resilience governance on public health crisis in china', International Journal of Environmental Research and Public Health. MDPI AG, 18(4), pp. 120. doi: 10.3390/ijerph18042123.

Wilson, S. (2020) 'Pandemic leadership: Lessons from New Zealand's approach to COVID-19', Leadership. SAGE Publications Ltd, 16(3), pp. 279-293. doi: $10.1177 / 1742715020929151$.

Wong, W. (2021) 'When the state fails, bureaucrats and civil society step up: analysing policy capacity with political nexus triads in the policy responses of Hong Kong to COVID-19', Journal of Asian Public Policy. Routledge. doi: 10.1080/17516234.2021.1894314.

Xiao, Y., Peng, Q. and Xu, W. (2021) 'Evolutionary Game Analysis of Cross-Regional Coordinated Governance of Major Public Health Emergencies: The Example of the Spread of the COVID19 Outbreak', Mathematical Problems in Engineering. Hindawi Limited, 2021. doi: $10.1155 / 2021 / 9992163$.

Zeemering, E. S. (2021) 'Functional fragmentation in city hall and Twitter communication during the COVID-19 Pandemic: Evidence from Atlanta, San Francisco, and Washington, DC', Government Information Quarterly. Elsevier Ltd, 38(1). doi: 10.1016/j.giq.2020.101539. 